\title{
Distal Volar
}

National Cancer Institute

\section{Source}

National Cancer Institute. Distal Volar. NCI Thesaurus. Code C147160.

Pertaining to the farthest portion from the palm side of a hand or the sole side of a foot. 